Original Article

Artigo Original

Ana Henriques Lima ${ }^{1}$

Ana Paula Hermont ${ }^{2}$ Amélia Augusta de Lima Friche ${ }^{1}$

Keywords

Pain

Analgesia

Sucking behavior

Newborn

Case-control studies

Descritores

Dor

Analgesia

Comportamento de sucção Recém-nascido

Estudos de casos e controles
Correspondence address:

Ana Paula Hermont

R. Benvinda de Carvalho, 105/202, Santo Antonio, Belo Horizonte (MG), Brazil, CEP: $30330-180$.

E-mail: anapaulahermont@gmail.com

Received: $01 / 17 / 2013$

\section{Analgesia in newborns: a case-control study of the efficacy of nutritive and non-nutritive sucking stimuli}

Analgesia em recém-nascidos: um estudo caso-controle da eficácia dos estímulos de sucção nutritiva e não nutritiva

\begin{abstract}
Purpose: To verify the nutritive and non-nutritive stimuli efficacy in the newborn's response to pain during venipuncture. Methods: The main sample was composed of 64 newborns that were randomly divided into three groups. The first group $(n=20)$ received nutritive sucking stimulus that was performed through maternal breastfeeding. The second group $(\mathrm{n}=21)$ received non-nutritive sucking stimulus that was performed through the introduction of the researcher little finger in the newborn's oral cavity. The third group or control group $(n=23)$ did not receive any analgesia stimulus. The newborns were evaluated using the Neonatal Infant Pain Scale, and the responses to painful stimuli were compared. Results: The nutritive as well as non-nutritive suction methods provided a comforting effect, resulting in lower pain response scores $(\mathrm{p}<0.05)$. There was no difference between the analgesia provided by both methods ( $p>0.05$ ). Conclusion: The nutritive and the nonnutritive sucking stimuli proved to be efficacious tools in relieving pain among newborns.
\end{abstract}

\section{RESUMO}

Objetivo: Verificar a eficácia dos estímulos de sucção nutritiva e não nutritiva na resposta do recém-nascido à dor durante a punção venosa. Métodos: A amostra principal foi composta por 64 recém-nascidos que foram divididos aleatoriamente em três grupos. O primeiro grupo $(n=20)$ recebeu estímulo de sucção nutritiva, o qual foi realizado através da amamentação materna. O segundo grupo $(\mathrm{n}=21)$ recebeu estímulo de sucção não nutritiva, o qual foi realizado através da introdução do dedo mínimo do pesquisador na cavidade oral do recém-nascido. O terceiro grupo ou grupo de controle $(n=23)$ não recebeu qualquer estímulo de analgesia. Os recém-nascidos foram avaliados utilizando a Escala de Dor do Recém-nascido e as respostas aos estímulos dolorosos foram comparadas. Resultados: Ambos os estímulos de sucção proporcionaram efeito analgésico, resultando em respostas a dor menores se comparados ao controle $(\mathrm{p}<0.05)$. Não houve diferença entre a analgesia produzida pelos dois estímulos de sucção ( $>0.05)$. Conclusão: Tanto o estímulo de sucção nutritiva quanto a sucção não nutritiva provaram ser métodos eficazes no alívio da dor em recém-nascidos.
Study carried out at the Universidade Federal de Minas Gerais - UFMG - Belo Horizonte (MG), Brasil. (1) Department of Speech Language Pathology and Audiology, Universidade Federal de Minas Gerais - UFMG Belo Horizonte (MG), Brazil.

(2) Department of Paediatric Dentistry and Orthodontics, Universidade Federal de Minas Gerais - UFMG Belo Horizonte (MG), Brazil.

Conflict of interest: nothing to declare. 


\section{INTRODUCTION}

Pain can be defined as an unpleasant sensorial and emotional experience associated with a real or potential injury to the body tissues ${ }^{(1)}$. It is a subjective sensation, and it is through painful experiences that occur from birth that each individual learns its meaning ${ }^{(1)}$. Until the beginning of the 1990s, the fact that newborns are capable of feeling pain was not well accepted by the medical community (2). It was thought that a newborn's nervous system was not developed enough in order to detect, localize, and perceive the painful stimulus as well as that the newborns did not have the capability of remembering the feeling of pain from the moment the painful stimulus was gone $^{(2)}$. Therefore, invasive procedures were performed without sedation or anesthesia ${ }^{(2)}$.

Nowadays, it is well known that from the seventh week of intrauterine life, the anatomical pathways responsible for pain sensitivity are already developed and by the twentieth week of intrauterine life, they are totally scattered through the body surface $^{(2)}$. A newborn modifies his physiological, behavioral, and psychological parameters during an acute painful stimulus in order to stop or limit the duration of the painful experience ${ }^{(1)}$. This process meanwhile requires great energy expenditure, leading to the increase of heart rate, blood pressure, the respiratory rate variability, and behavioral modifications, such as crying and specific facial expressions ${ }^{(3)}$. Supposing persistent painful experiences happen, increased pain sensitivity might occur and the newborn can become less responsive to pain if the protective mechanisms are overwhelmed. Therefore, it can lead to short-term consequences such as irritation, decreased attention and guidance, changes in sleep patterns, and decreased appetite or refusal to feed and may even have influence on the mother-newborn relationship ${ }^{(4)}$. The prolonged painful stimulus causes sequelae in the medium- and long-term periods ${ }^{(4)}$. There may be enhanced sensitivity to pain and hypersensitivity to potentially painful or nonpainful stimuli due to the increase of nerve branches at the repeatedly assaulted site and decreased pain threshold ${ }^{(4)}$.

Knowledge about the pain effects in the neonatal period has stimulated professionals in the health area to search for pharmacological and nonpharmacological mechanisms capable of reducing or eliminating the pain ${ }^{(5)}$. Nevertheless, in most cases newborns are submitted to painful diagnostic procedures shortly after their birth without the adequate analgesia causing pain and discomfort ${ }^{(6)}$. Some studies indicate nutritive sucking (NS) and non-nutritive sucking (NNS) as efficacious procedures in relieving pain in newborns ${ }^{(7-9)}$. The NS includes breast and bottle feeding whereas the NNS may include sucking on digit, pacifier, or other objects without the presence of any liquid ${ }^{(10,11)}$.

The present study aimed to investigate the analgesic potential of the NS and NNS stimuli among newborns undergoing venipuncture. The importance of checking the efficacy of both methods remains in the fact that it could be used in the hospital and ambulatorial clinical practice in a routine basis, requiring no additional costs, in order to provide pain relief in pursuit of improvements in a newborns' care and their quality of life.

\section{METHODS}

A case-control study was conducted with a sample composed of 64 newborns with medical requests for venipuncture. The newborns were randomly chosen from the rooming-in of Hospital das Clínicas of the Federal University of Minas Gerais. All newborns suffering from neurological damage, head and neck malformations, and heart diseases or with absence of sucking reflex or motion were excluded. Gestational age was not a selection criterion. Prior to enrolling in the study the parents/ guardians of the newborns provided informed consent by agreeing to participate in the research and signing an Informed Consent Form. The research was approved by the Human Research Ethics Committee and by the Board of Education and Research of Hospital das Clínicas of the Federal University of Minas Gerais.

The data collection was performed in partnership with the blood collection services from the rooming-in of Hospital das Clínicas. The newborns were randomly divided into three groups. The first group (Group 1) and the second group (Group 2) consisted of 20 newborns who received the NS stimulation and of 21 newborns who received NNS stimulation before and during the venipuncture, respectively. The third group or control group (Group 3) consisted of 23 newborns who did not receive any sucking stimulation.

The NS and NNS stimuli were started 2 minutes before the venipuncture, were continued through the puncture, and were maintained until 1 minute after the painful procedure completion. The NS stimulation was performed through maternal breastfeeding. The mothers were instructed on the proper latch and positioning of the newborn. The NNS stimulus was performed through the introduction of the researcher little finger in the newborn's oral cavity. The finger was protected by nonsurgical examination gloves.

The Neonatal Infant Pain Scale (NIPS) ${ }^{(12)}$ was used to evaluate the clinical status and behavior of the three groups during the venipuncture. It is a behavioral assessment tool for measuring pain in preterm and full-term newborns and can be used to monitor a newborn before, during, and after a painful procedure. The scale consists of six parameters of pain which are facial expression, crying, arms and legs movements, state of arousal and breathing patterns, five behavioral indicators, and one physiological indicator. The newborns were given a score for each one of the six pain indicators ranging from 0 to 1 , with exception to the crying parameter which ranges from 0 to 2 points. Total scores greater than 3 points (NIPS $>3$ ) indicate the presence of pain. The maximum score that can be obtained is 7 points, corresponding to the highest score for pain. All stimulation and evaluation procedures were performed by the same researcher who was previously trained by a gold standard.

The final scores of pain obtained using the NIPS were categorized, checking whether the NS and NNS stimuli interfered with the results. Newborns who achieved NIPS $>3$ points were classified as "felt pain" and the NIPS $\leq 3$ as "no pain." Finally, the final results obtained among the groups were compared.

A descriptive analysis of the data was performed using measures of central tendency and dispersion for the continuous 
variables and frequency distribution for the categorical variables. The association between the presence of pain and the other variables was assessed using the Chi-square test with a level of statistical significance of 0.05 . Data were tabulated and analyzed using the Statistical Package for the Social Sciences (SPSS for Windows, version 17.0, SPSS Inc., Chicago, IL, USA).

\section{RESULTS}

The target sample consisted of 64 newborns - 36 females and 28 males. In Group $1(n=20)$, all newborns were born with gestational age of $\geq 37$ weeks and the majority $(n=12)$ were male. In Group $2(n=21)$, two were born with gestational age of $<37$ weeks, and 13 were male. In the control group ( $n=23$ ), four were born with gestational age of $\leq 37$ weeks and the majority were female (Table 1).

There was no statistically significant difference between the response to the painful stimuli when evaluating the gender and gestational age variables.

The prevalence of pain increased significantly when comparing the newborns from Group 1, who received NS stimulation with those from Group 3, who received no sucking stimulation. The prevalence of pain also increased when comparing Group 2 (NNS stimulus) and Group 3, suggesting the efficacy of the sucking stimuli on pain relief among newborns (Table 2).

No statistically significant difference was found when comparing the effects of the NS and NNS stimuli in the newborn's pain relief (Table 2).

\section{DISCUSSION}

On the basis of our results, it can be stated that the NS and NNS methods have proven to be efficacious in relieving pain among newborns undergoing venipuncture. This finding is

Table 1. Profile of the sample - Group 1 (newborns who received nutritive sucking stimulus), Group 2 (newborns who received non-nutritive sucking stimulus), and Group 3 (newborns who received no analgesia stimulus)

\begin{tabular}{lcccc}
\hline Characteristics & $\begin{array}{c}\text { Group 1 } \\
(\mathrm{n}=20) \\
\mathrm{n}(\%)\end{array}$ & $\begin{array}{c}\text { Group 2 } \\
(\mathrm{n}=21) \\
\mathrm{n}(\%)\end{array}$ & $\begin{array}{c}\text { Group 3 } \\
(\mathrm{n}=23) \\
\mathrm{n}(\%)\end{array}$ & $\begin{array}{c}\text { Total } \\
(\mathrm{n}=64) \\
\mathrm{n}(\%)\end{array}$ \\
\hline $\begin{array}{l}\text { Gender } \\
\text { Male }\end{array}$ & $12(60.0)$ & $13(61.9)$ & $11(47.8)$ & $36(56.2)$ \\
$\quad$ Female & $8(40.0)$ & $8(38.1)$ & $12(52.2)$ & $28(43.8)$ \\
Gestational age & & & & \\
$\quad<37$ weeks & $0(0.0)$ & $2(9.5)$ & $4(17.4)$ & $6(9.4)$ \\
$\geq 37$ weeks & $20(100.0)$ & $19(90.5)$ & $19(82.6)$ & $58(90.6)$ \\
Weight (g) & & & & \\
$<2,500$ & $2(10.0)$ & $4(19.0)$ & $9(39.0)$ & $15(23.4)$ \\
$\geq 2,500$ & $18(90.0)$ & $17(81.0)$ & $14(61.0)$ & $19(76.6)$ \\
Pain & & & & \\
Present & $7(35.0)$ & $5(23.8)$ & $19(82.6)$ & $31(48.5)$ \\
Absent & $13(65.0)$ & $16(76.2)$ & $4(17.4)$ & $33(51.5)$ \\
\hline
\end{tabular}

Table 2. Comparative profile of pain between Group 1 (received nutritive sucking stimulus), Group 2 (received non-nutritive sucking stimulus) and Group 3 (received no analgesia stimulus)

\begin{tabular}{lcccc}
\hline Groups & $\begin{array}{c}\text { Presence } \\
\text { of pain } \\
\mathrm{n}(\%)\end{array}$ & $\begin{array}{c}\text { Absence } \\
\text { of pain } \\
\mathrm{n}(\%)\end{array}$ & $\begin{array}{c}\text { Total } \\
\mathrm{n}(\%)\end{array}$ & p-value* \\
\hline 1 & $7(58.3)$ & $13(44.8)$ & $20(48.8)$ & 0.874 \\
2 & $5(41.7)$ & $16(55.1)$ & $21(51.2)$ & \\
\hline 1 & $7(26.9)$ & $13(76.5)$ & $20(46.5)$ & 0.001 \\
3 & $19(73.1)$ & $4(23.5)$ & $23(53.5)$ & \\
\hline 2 & $5(20.8)$ & $16(80.0)$ & $21(47.7)$ & $<0.001$ \\
3 & $19(79.2)$ & $4(20.0)$ & $23(52.3)$ & \\
\hline
\end{tabular}

*Pearson's $\chi^{2}$ test.

supported by other studies, which confirm the efficacy of both methods and also affirm that the effects produced by the NS may be potentiated by the association of a sucrose solution ${ }^{(6,9,13-15)}$. Nevertheless, the analgesic potential provided by the sucking methods mentioned should not be overstated, although the comforting effect they provided resulting in lower pain response scores is remarkable. Studies relating the prevalence of pain in newborns with different genders were not found.

It is worth noticing that when comparing all the three groups, there was a statistically significant difference between the response to painful stimuli, once the control group had significantly higher pain scores than newborns from the intervention groups $(\mathrm{p}<0.001)$ (Table 2). Nevertheless, no studies comparing the analgesic potential of NS and NNS methods were found in the literature, making it impossible to compare the results in the present research with findings from other studies.

The NIPS ${ }^{(12)}$ used in this research proved to be a practical and useful instrument concerning the assessment of pain among newborns. This data is consistent with previously published data asserting that NIPS is an efficacious scale regarding the evaluation of newborns undergoing painful procedures ${ }^{(12,16)}$.

Despite the use of NS stimulus in the rooming-in as a mean of pain relieving ${ }^{(17-19)}$, the lack of knowledge by some professionals who deal with newborns care regarding nonpharmacological methods of pain relief was observed. This finding emphasizes the importance of raising awareness among professionals who work directly or indirectly with newborns about the accurate recognition and identification of pain as well as the need for inclusion of an efficacious curriculum to improve the patient's pain assessment and management ${ }^{(2,19)}$.

Besides contributing to the analgesia of the newborns, the NS and NNS methods were also efficacious for calming down the newborn during the painful procedure, thus endorsing statements made by other studies which are in agreement with the presented findings ${ }^{(5,7)}$.

The importance of using the NS and NNS stimuli in a routine basis at hospitals, as proposed in this research, is justified by reports arguing that newborns are capable of feeling pain, and the painful phenomenon which is not properly managed in this period of life may cause changes in pain sensitivity, as well as development modifications in childhood and even in the adult stage $\mathrm{e}^{(4,8)}$. 
It is well known that speech therapists work closely with the care-provider team in neonatal intensive care units in order to help the newborn transition to oral feeds ${ }^{(20)}$. Therefore, the NNS that has been used by professionals in speech performance in this process of transition to oral feeding must also be considered as a technique to manage the pain among newborns undergoing a painful procedure such as venipuncture.

It is worth mentioning the need for further studies on nonpharmacological methods of pain relief so that a solid argument can be made regarding the effects of nonpharmacological analgesic stimuli among different subgroups of newborns. As a limitation of the present research, it is important to stress that the venipuncture procedure was not performed by the same professional, and this may have interfered with the pain response of each newborn. Moreover, the comfort measure of being held by the mother has to be taken into account as a potential compounding variable.

\section{CONCLUSION}

The NS and NNS stimuli proved to be efficacious methods in providing a comforting effect among newborns undergoing venipuncture. This is an important finding not only with regard to the pain issues but it corroborates with the Baby Friendly Hospital Initiative launched by WHO and UNICEF, which is a worldwide program aiming to protect, promote, and support breastfeeding.

*AHL collected and analyzed the data, drafted the initial manuscript and approved the final manuscript submitted; APH took part in the statistical analysis, critically revised the initial manuscript and approved the final manuscript submitted; AALF accompanied the data collection, collaborated with the data analysis, and was responsible for the study design and general orientation of stages of execution and manuscript preparation.

\section{REFERENCES}

1. Anand KJ, Hickey PR. Pain and its effects in the human neonate and fetus. N Engl J Med. 1987;317(21):1321-7.

2. Morton NS. The pain-free ward: myth or reality. Paediatr Anaesth. 2012;22(6):527-9.
3. Kristjánsdóttir O, Unruh AM, McAlpine L, McGrath PJ. A systematic review of cross-cultural comparison studies of child, parent, and health professional outcomes associated with pediatric medical procedures. J Pain. 2012;13(3):207-19.

4. American Academy of Pediatrics, Canadian Paediatric Society. Prevention and Management of Pain in the Neonate: An Update. Pediatrics. 2006;118(5):2231-41.

5. Hardy W. Facilitating pain management. Adv Neonatal Care. 2011;11(4):279-81.

6. Gaspardo CM, Miyase CI, Chimello JT, Martinez FE, Martins Linhares MB. Is pain relief equally efficacious and free of side effects with repeated doses of oral sucrose in preterm neonates? Pain. 2008;137(1):16-25.

7. Corff KE, Seideman R, Venkataraman PS, Lutes L, Yates B. Facilitated tucking: a nonpharmacologic comfort measure for pain in preterm neonates. J Obstet Gynecol Neonatal Nurs. 1995;24(2):143-7.

8. Mathew PJ, Mathew JL. Assessment and management of pain in infants. Postgrad Med J. 2003;79(934):438-43.

9. Gray L, Miller LW, Philipp BL, Blass EM. Breastfeeding is analgesic in healthy newborns. Pediatrics. 2002;109(4):590-3.

10. Glass RP, Wolf LS. A global perspective on feeding assessment in the neonatal intensive care unit. Am J Occup Ther. 1994;48(6):514-26.

11. Hall RW. Anesthesia and analgesia in the NICU. Clin Perinatol. 2012;39(1):239-54.

12. Lawrence J, Alcock D, McGrath P, Kay J, MacMurray SB, Dulberg C. The development of a tool to assess neonatal pain. Neonatal Netw. 1993;12(6):59-66.

13. Blass EM. Milk-induced hypoalgesia in human newborns. Pediatrics. 1997;99(6):825-9.

14. Carbajal R, Chauvet X, Couderc S, Olivier-Martin M. Randomised trial of analgesic effects of sucrose, glucose, and pacifiers in term neonates. BMJ. 1999;319(7222):1393-7.

15. Stevens B, Johnston C, Petryshen P, Taddio A. Premature infant pain profile: development and initial validation. Clin J Pain. 1996;12(1):13-22.

16. Butler-O'Hara M, LeMoine C, Guillet R. Analgesia for neonatal circumcision: A randomized controlled trial of EMLA cream versus dorsal penile nerve block. Pediatrics. 1998;101(4):1-5.

17. Fernandes A, Campbell-Yeo M, Johnston CC. Procedural pain management for neonates using nonpharmacological strategies: Part 1: sensorial interventions. Adv Neonatal Care. 2011;11(4):235-41.

18. Liu MF, Lin KC, Chou YH, Lee TY. Using non-nutritive sucking and oral glucose solution with neonates to relieve pain: a randomised controlled trial. J Clin Nurs. 2010;19(11-12):1604-11.

19. Weissman A, Aranovitch M, Blazer S, Zimmer EZ. Heel-lancing in newborns: Behavioral and spectral analysis assessment of pain control methods. Pediatrics. 2009;124(5):921-6.

20. Zimmerman EA, Barlow SM. The complexity of transitioning to oral feeds in preterm infants. Perspect Speech Sci Orofac Disord. 2009;19(1):52-7. 